\title{
Respons Pertumbuhan Tanaman Labu Kuning (Cucurbita moschata) Pada Cekaman Salinitas
}

\author{
Melysa Indah Sari ${ }^{*}$, Shafa Noer ${ }^{2}$, Emilda $^{3}$ \\ ${ }^{1}$ Fakultas MIPA, Program Studi Pendidikan Biologi, Universitas Indraprasta PGRI \\ *email: shafa_noer@yahoo.co.id
}

\begin{tabular}{l} 
Article History \\
\hline Received: \\
11/01/2022 \\
Revised: \\
22/01/2022 \\
Accepted: \\
26/01/2022 \\
\\
Kata kunci: \\
Cekaman \\
salinitas \\
Pertumbuhan \\
Labu kuning
\end{tabular}

Key word: Salinity stress Growth Pumpkin

\begin{abstract}
ABSTRAK
Pada setiap tanaman memiliki perbedaan yang beragam pada toleransi terhadap cekaman salinitas. Penelitian ini bertujuan untuk mengetahui respons pertumbuhan tanaman labu kuning (Cucurbita moshcata) pada cekaman salinitas. Pelaksanaan penelitian ini yaitu di Kebun Percobaan Biologi Universitas Indraprasta PGRI mulai April 2021 sampai dengan Juli 2021. Parameter pertumbuhan yang diamati dalam penelitian ini adalah tinggi tanaman, jumlah daun, dan panjang akar. Metode penelitian yang digunakan yaitu eksperimen murni dengan metode kuantitatif. Desain penelitian menggunakan Rancangan Acak Lengkap (RAL). Faktor yang diuji yaitu larutan garam $(\mathrm{NaCl})$ dengan konsentrasi berbeda yaitu 0 ppm (kontrol), 1000 ppm, 3000 ppm, dan 6000 ppm, masingmasing dengan pengulangan sebanyak 5 kali, sehingga jumlah sampel seluruhnya adalah 20 tanaman labu kuning. Masing-masing pemberian konsentrasi larutan $\mathrm{NaCl}$ tersebut memberikan hasil yang berbeda-beda. Hasil penelitian menunjukkan bahwa adanya cekaman salinitas dapat mengganggu proses pengangkutan unsur hara, sehingga pertumbuhan vegetatif tanaman dapat terganggu. Oleh karena itu, semakin tinggi tingkat salinitas, pertumbuhan tinggi tanaman, jumlah daun, dan pertumbuhan akar tanaman labu kuning semakin lambat bahkan mengalami kematian.
\end{abstract} \begin{abstract}
Each plant has various differences in tolerance to salinity stress. This study aims to determine the growth response of pumpkin (Cucurbita moshcata) in salinity stress. The implementation of this research is at the Biology Experimental Garden, Indraprasta University PGRI starting from April 2021 to July 2021. The growth parameters observed in this study were plant height, number of leaves, and root length. The research method used is pure experiment with quantitative methods. The research design used a completely randomized design (CRD). The factorial behavior pattern consists of one factor, namely salt solution $(\mathrm{NaCl})$ with different concentrations of 0 ppm (control), 1000 ppm, 3000 ppm, and 6000 ppm, each with 5 repetitions, so the total sample is 20 plants. summer squash. Each concentration of $\mathrm{NaCl}$ solution gave different results. The results showed that salinity stress could interfere with the nutrient transport process, so that plant vegetative growth could be disrupted. Therefore, the higher the salinity level, the slower the growth of plant height, number of leaves, and root growth of pumpkin plants, even death.
\end{abstract}

Copyright @ 2022 LPPM Universitas Indraprasta PGRI. All Right Reserved

\section{PENDAHULUAN}

Sebagai salah satu makhluk hidup, tanaman sangat tergantung dengan kondisi lingkungan untuk dapat tumbuh dan berkembang dengan baik. Lingkungan dapat berubah-ubah tergantung dari berbagai faktor. Perubahan ini dapat sesuatu yang masih bisa ditoleransi oleh tanaman tersebut atau sesuatu yang tidak dapat ditoleransi. Ketika tanaman tidak dapat mentolerir perubahan lingkungan maka hal ini akan berdampak langsung pada tanaman seperti turunnya produktivitas tanaman atau bahkan dapat menyebabkan kematian.

Pertumbuhan tanaman dapat dipengaruhi oleh dua faktor yaitu faktor internal yang berasal dari tanaman itu sendiri dan faktor lingkungan yang berasal dari lingkungan tumbuhnya. Pada umumnya tanaman dapat terkontak dengan berbagai macam cekaman lingkungan yang dapat 
mengganggu pertumbuhan dan perkembangannya, seperti pembekuan, kekeringan dan salinitas atau kadar garam yang tinggi (Afifah, 2014).

Luas lahan pertanian saat ini mulai berkurang terutama di perkotaan, namun kebutuhan sumber karbohidrat sebagai pangan pokok harus tetap terpenuhi. Bertambahnya jumlah penduduk dan alih fungsi lahan pertanian menjadi pabrik, pemukiman penduduk, maupun sarana transportasi, maka mendorong untuk pemanfaatan lahan-lahan suboptimal. Diantara masalah yang muncul pada lahan marginal adalah terdapat berbagai cekaman lingkungan, salah satunya yang dijumpai adalah salinitas.

Salinitas menjadi salah satu faktor yang dapat menghambat pertumbuhan tanaman (Djukri, 2009). Garam Natrium Klorida $(\mathrm{NaCl})$ sebenarnya merupakan salah satu garam terlarut yang terdapat di dalam tanah yang merupakan unsur penting bagi pertumbuhan tanaman. Namun, apabila kadar larutan garam ini terdapat dalam jumlah yang berlebihan justru akan mengganggu pertumbuhan (Tavakkoli $d k k$., 2010).

Perubahan iklim merupakan salah satu sebab terjadinya perubahan kadar salinitas, misalnya suhu menjadi sangat tinggi. Subu tinggi menyebabkan penguapan (evaporasi) dan mengakibatkan garam terakumulasi di dalam tanah sehingga kadar salinitas tanah menjadi tinggi (Afifah, 2014). Garam yang berada di dalam tanah juga dapat berasal dari beberapa kandungan pupuk kimia yang menumpuk dan berkumpul dalam tanah (Andriani, 2017). Sedang Djukri (2009) menyebutkan kadar $\mathrm{NaCl}$ dalam tanah dapat terjadi karena tingginya masukan air yang mengandung garam atau karena mengalami tingkat evaporasi yang melebihi presipitasi.

Tingginya kadar salinitas dapat berdampak pada menutupnya stomata, sehingga mengurangi kadar $\mathrm{CO}_{2}$ di dalam daun dan berakibat terhambatnya fiksasi karbon. Selain itu, salinitas juga menyebabkan tanaman menjadi dehidrasi atau kekurangan air. Sifat cekaman garam ini juga merupakan sesuatu yang sangat kompleks dan dapat mempengaruhi tekanan osmotik dan ionik sehingga secara langsung akan mempengaruhi kebutuhan nutrisi tanaman yang berpengaruh pada proses perkembangan tanaman (Yunita, 2018).

Tanaman labu kuning (Cucurbita moschata) termasuk tanaman pangan yang dikembangkan sebagai pengganti sumber karbohidrat terutama beras, karena labu kuning memiliki kandungan gizi hampir sama dengan padi. Kusumawati (2013) menyatakan buah labu kuning memiliki kandungan gizi yang baik berupa vitamin, karbohidrat, serat, dan vitamin. Selain itu, labu kuning juga terkandung 34 kalori, 0.8 lemak, 45 mg kalsium, dan 0.8 mineral. Oleh karena itu labu kuning sangat baik dikonsumsi untuk kesehatan tubuh.

Untuk meningkatkan produksi labu kuning diperlukan penambahan areal tanam. Pada lahan optimal, tanaman labu kuning akan bersaing dengan tanaman pangan atau hortikultura lainnya seperti melon dan semangka. Upaya perluasan areal tanam ini dapat dilakukan pada lahan suboptimal termasuk pada lahan dengan salinitas tinggi.

Lahan salin dianggap kurang sesuai ditanami tanaman pangan. Padahal di Indonesia lahan ini cukup luas yaitu sekitar 0.4 juta ha di antaranya terdapat di sepanjang pantai utara dan selatan Jawa, Aceh, dan Nias akibat tsunami, Sulawesi Selatan, Flores, Jambi dan, Kalimantan (Trustinah, 2020). Bahkan berpotensi bertambah seiring dampak perubahan iklim dan aktifitas manusia.

Pemanfaatan lahan salin untuk pertanian dapat dilakukan dengan pemilihan varietas tanaman yang toleran terhadap kondisi salinitas serta melakukan pengelolaan tanah supaya sesuai dengan kebutuhan tanaman. Langkah awal untuk memperoleh varietas tanaman yang toleran terhadap cekaman salinitas yaitu dengan melakukan uji ketahanan tanaman untuk dilihat tingkat toleransinya berdasarkan kadar garam $\mathrm{NaCl}$ yang digunakan.

Tanaman labu kuning memiliki kemampuan adaptasi yang tinggi, sehingga dapat tumbuh di daerah dataran rendah maupun dataran tinggi (Zufahmi, 2015). Hanya saja tanaman ini memiliki daya tahan yang berbeda dalam hal toleransinya terhadap berbagai cekaman lingkungan, sehingga pengaruh terhadap aktivitas kehidupan pun akan bervariasi. Sebagaimana pada tanaman lainnya, pengaruh cekaman lingkungan yang bervariasi menyebabkan bentuk adaptasi tanaman yang berbeda-beda.

Berbagai jenis tanaman mempunyai daya tahan yang berbeda terhadap kondisi salinitas, sehingga pengaruh terhadap aktivitas metabolismenya juga bervariasi. Seperti pada tanaman cabai rawit, bentuk adaptasinya terhadap salinitas dengan cara menurunkan berat kering tanaman serta hasil panen (Bastomi, 2018). Sedangkan pada tanaman kedelai, menurut Purwaningrahayu (2016) memiliki toleransi yang berbeda pada salinitas 
tergantung varietasnya. Pertumbuhan tanaman kedelai mulai terganggu pada kadar garam lebih dari $0.01 \%$ (setara $0.15 \mathrm{dS} / \mathrm{m}$ ).

Tujuan dari penelitian ini adalah untuk melihat respons pertumbuhan tanaman labu kuning (Cucurbita moschata) terhadap cekaman salinitas.

\section{METODE PENELITIAN}

Penelitian ini dilaksanakan pada April 2021 hingga Juli 2021 di Kebun Percobaan Biologi, Universitas Indraprasta PGRI. Jenis penelitian ini yaitu eksperimen murni dengan metode kuantitatif. Desain penelitian yang digunakan adalah Rancangan Acak Lengkap (RAL).

Faktor dalam penelitian ini yaitu larutan garam $(\mathrm{NaCl})$ dengan konsentrasi berbeda. Penelitian ini dilaksanakan dengan pembagian 4 perlakuan yaitu 0 ppm (kontrol), 1000 ppm, 3000 ppm, dan 6000 ppm, masing-masing dengan pengulangan sebanyak 5 kali, sehingga jumlah sampel seluruhnya adalah 20 tanaman labu kuning. Pengamatan dilakukan selama 1 minggu sekali selama 5 minggu.

Metode pengumpulan data pada penelitian ini terdiri dari penentuan variabel penelitian dan prosedur penelitian. Sumber data yang digunakan oleh peneliti yaitu berasal dari peninjauan langsung tanaman labu kuning (Cucurbita moschata) yang ditanam. Variabel bebas yang digunakan yaitu pengamatan pengaruh cekaman garam $(\mathrm{NaCl})$, sedangkan variabel terikatnya yaitu dengan pengamatan pertumbuhan tanaman labu kuning (Cucurbita moschata) meliputi tinggi tanaman, jumlah daun, dan panjang akar.

Penelitian ini menggunakan statistik deskriptif untuk menyajikan dan mendeskripsikan data mentah menjadi bentuk tabel, gambar, atau grafik dan statistik diferensial untuk untuk uji hipotesis. Data mentah hasil penelitian diolah menggunakan perhitungan dan bantuan komputer dengan program SPSS. Data yang telah terkumpul kemudian dilakukan uji hipotesis penelitian dengan menggunakan uji ANOVA satu arah, jika terdapat perbedaan dilanjutkan dengan uji lanjut LSD (Least Significant Difference) dengan signifikansi $5 \%(0,05)$.

\section{HASIL DAN PEMBAHASAN}

Pertumbuhan tanaman labu kuning (Cucurbita moschata) dapat dilihat dari parameter pertumbuhan yang diamati pada penelitian ini yaitu tinggi tanaman, jumlah daun, dan panjang akar.
Waktu pengukuran dimulai dari 14, 21, 28, dan 35 Hari Setelah Tanam (HST). Pengukuran tinggi tanaman, jumlah daun, dan panjang akar tanaman dilakukan secara berkala pada waktu sore hari. Saat persemaian selesai, tanaman labu kuning dipindahkan ke dalam polibag setelah 14 hari penanaman. Terdapat 20 unit sampel percobaan dengan konsentrasi yang berbeda.

\section{Tinggi Tanaman Labu Kuning}

Pengukuran tinggi tanaman labu kuning (Cucurbita moschata) dilakukan dengan cara mengukur tinggi tanaman dari permukaan tanah sampai ke ujung batang tanaman dengan menggunakan penggaris. Pengukuran tinggi tanaman labu kuning dilakukan sebanyak 5 kali pengulangan.

Hasil uji hipotesis menggunakan ANOVA satu arah menunjukkan bahwa tinggi tanaman labu kuning pada waktu 14, 28, dan 35 HST memiliki $\mathrm{F}_{\text {hitung }}>$ nilai $\mathrm{F}_{\text {tabel }}$, maka $\mathrm{H}_{0}$ ditolak dan dapat disimpulkan bahwa terdapat perbedaan pengaruh yang signifikan tinggi tanaman labu kuning pada cekaman salinitas. Sedangkan pada waktu 21 HST memiliki $\mathrm{F}_{\text {hitung }}(2,866)<$ dari nilai $\mathrm{F}_{\text {tabel }}(3,24)$, maka $\mathrm{H}_{0}$ diterima dan dapat disimpulkan bahwa tidak terdapat perbedaan pengaruh yang signifikan pada tinggi tanaman labu kuning.

Tabel 1. Uji ANOVA 1 arah pada tinggi tanaman labu kuning (Cucurbita moschata)

\begin{tabular}{cccc}
\hline $\begin{array}{c}\text { Waktu } \\
\text { (HST) }\end{array}$ & $\mathrm{F}_{\text {hitung }}$ & $\mathrm{F}_{\text {tabel }}$ & Keterangan \\
\hline 14 & 3.572 & 3.24 & $\mathrm{H}_{0}$ ditolak, terima $\mathrm{H}_{1}$ \\
21 & 2.866 & 3.24 & $\mathrm{H}_{0}$ diterima, tolak $\mathrm{H}_{1}$ \\
28 & 6.675 & 3.24 & $\mathrm{H}_{0}$ ditolak, terima $\mathrm{H}_{1}$ \\
35 & 15.576 & 3.24 & $\mathrm{H}_{0}$ ditolak, terima $\mathrm{H}_{1}$ \\
\hline
\end{tabular}

Data pada Tabel 2 merupakan data rata-rata tinggi tanaman labu kuning mulai dari 14 hingga 35 HST pada masing-masing perlakuan. Berdasarkan hasil uji lanjut pada tinggi tanaman labu kuning, perlakuan cekaman salinitas yang paling berpengaruh yaitu pada perlakuan konsentrasi $6000 \quad\left(\mathrm{P}_{3}\right)$. Pada konsentrasi ini pertumbuhan tinggi tanaman labu kuning menjadi lebih lambat.

Pertumbuhan tinggi tanaman labu kuning yang paling baik dalam penelitian ini yaitu tanaman labu kuning yang tidak diberikan perlakuan cekaman salinitas atau pada konsentrasi 0 ppm. Hal ini diperkuat oleh hasil penelitian Novita $d k k$. (2019) bahwa tanaman yang diberikan perlakuan tanpa salinitas, pertumbuhannya jauh lebih baik daripada 
tanaman yang diberi cekaman salinitas. Tinggi tanaman terhambat akibat kadar salinitas yang tinggi karena kadar air dalam jaringan. Rendahnya kadar air dalam jaringan tanaman disebabkan daya serap tanaman yang rendah. Hal ini mengakibatkan aktivitas meristem apikal menjadi terganggu dan berpengaruh pada perkembangan dan pertumbuhan sel (Kusumiyati $d k k .$, 2017).

Tabel 2. Pengaruh cekaman salinitas terhadap reata tinggi $(\mathrm{cm})$ tanaman labu kuning (Cucurbita moschata)

\begin{tabular}{ccccc}
\hline Perlakuan & $14 \mathrm{HST}$ & $21 \mathrm{HST}$ & $28 \mathrm{HST}$ & $35 \mathrm{HST}$ \\
\hline $\mathrm{P}_{0}$ & $8.3 \mathrm{~b}$ & $10.9 \mathrm{a}$ & $13.1 \mathrm{~b}$ & $16.1 \mathrm{c}$ \\
$\mathrm{P}_{1}$ & $8.1 \mathrm{~b}$ & $10.8 \mathrm{a}$ & $11.8 \mathrm{~b}$ & $13.1 \mathrm{~b}$ \\
$\mathrm{P}_{2}$ & $7.8 \mathrm{~b}$ & $10.7 \mathrm{a}$ & $11.7 \mathrm{~b}$ & $12.7 \mathrm{~b}$ \\
$\mathrm{P}_{3}$ & $6.4 \mathrm{a}$ & $8.8 \mathrm{a}$ & $9.7 \mathrm{a}$ & $10.9 \mathrm{a}$ \\
\hline
\end{tabular}

Keterangan:

$\mathrm{P}_{0}=0$ ppm, $\mathrm{P}_{1}=1000 \mathrm{ppm}, \mathrm{P}_{2}=3000 \mathrm{ppm}, \mathrm{P}_{3}=6000 \mathrm{ppm}$.

Gangguan pertumbuhan tanaman yang tercekam salin memasuki fase kritisnya pada masa perkecambahan biji, dan dilanjutkan pada fase pertumbuhan vegetatif dan generatif (Purwaningrahayu, 2016). Mekanisme penghambatan perkecambahan dan pembibitan pertumbuhan dengan $\mathrm{NaCl}$, mungkin terkait dengan munculnya radikula karena penyerapan air tidak mencukupi, atau mungkin berasal efek toksik pada embrio (Azza et al., 2007 dalam Yamika dkk, 2016). Pada tanaman yang peka salinitas, kadar garam yang tinggi menghambat pertumbuhan dan perluasan daun, selanjutnya berpengaruh terhadap penurunan hasil biji. Shanon (1998) dalam Purwaningrahaya (2016), melaporkan bahwa salinitas dapat membatasi produksi tanaman akibat tingginya salinitas, menurunnya potensial air dan induksi stress ion serta cekaman oksidatif sekunder.

\section{Jumlah Daun Tanaman Labu Kuning}

Jumlah daun tanaman labu kuning yang terhitung ialah jumlah helaian daun yang sudah terbuka sempurna. Pengukuran jumlah daun tanaman labu kuning dilakukan sebanyak lima kali pengulangan.

Berdasarkan hasil output program SPSS bahwa data jumlah daun tanaman labu kuning pada waktu pengamatan 14 dan 21 HST tidak berdistribusi normal, maka uji hipotesis yang digunakan berupa uji non-parametrik yaitu uji Kruskal-Wallis. Adapun nilai signifikansi (Asymp. Sig) memiliki probabilitas 0.05 . Sedangkan pada waktu pengamatan 28 dan 35 HST uji hipotesis menggunakan ANOVA satu arah dengan nilai $\mathrm{F}_{\text {tabel }}$ adalah $\alpha(5 \%)=0.05, \mathrm{dk}_{1}(\mathrm{k}-1)=4-1=$ 3 dan $\mathrm{dk}_{2}\left(\mathrm{n}_{\mathrm{T}}-\mathrm{k}\right)=20-4=16$. Jadi, nilai $\mathrm{F}_{\text {tabel }}$ yang didapat adalah 3.24. Nilai $F_{\text {hitung dari }}$ masing-masing perlakuan dapat dilihat pada Tabel 3.
Hasil uji hipotesis menggunakan KruskalWallis, dapat terlihat bahwa jumlah daun tanaman labu kuning pada waktu 14 HST memiliki nilai Asymp. Sig (0.489) $>0.05$ maka $\mathrm{H}_{0}$ diterima dan pada 21 HST memiliki nilai Asymp. Sig (0.452) > $0.05 \mathrm{H}_{0}$ diterima, sehingga dapat disimpulkan bahwa pada waktu pengamatan 14 dan 21 HST tidak terdapat perbedaan pengaruh yang signifikan pada jumlah daun tanaman labu kuning pada cekaman salinitas.

Tabel 3. Uji Kruskal-Wallis pada jumlah daun tanaman labu kuning (Cucurbita moschata)

\begin{tabular}{cccl}
\hline $\begin{array}{c}\text { Waktu } \\
\text { (HST) }\end{array}$ & Chi-Square & Asymp. Sig & \multicolumn{1}{c}{ Keterangan } \\
\hline 14 & 2.426 & 0.489 & $\begin{array}{l}\mathrm{H}_{0} \text { diterima, } \\
\text { tolak } \mathrm{H}_{1}\end{array}$ \\
21 & 2.631 & 0.452 & $\begin{array}{l}\mathrm{H}_{0} \text { diterima, } \\
\text { tolak } \mathrm{H}_{1}\end{array}$ \\
\hline
\end{tabular}

Tabel 4. Uji ANOVA 1 Arah pada jumlah daun tanaman labu kuning (Cucurbita moschata)

\begin{tabular}{cccc}
\hline $\begin{array}{c}\text { Waktu } \\
\text { (HST) }\end{array}$ & $\mathrm{F}_{\text {hitung }}$ & $\mathrm{F}_{\text {tabel }}$ & \multicolumn{1}{c}{ Keterangan } \\
\hline 28 & 5.481 & 3.24 & $\begin{array}{l}\mathrm{H}_{0} \text { ditolak, } \\
\text { terima } \mathrm{H}_{1}\end{array}$ \\
35 & 7.042 & 3.24 & $\begin{array}{l}\mathrm{H}_{0} \text { ditolak, terima } \\
\mathrm{H}_{1}\end{array}$ \\
\hline
\end{tabular}

Hasil uji hipotesis menggunakan ANOVA satu arah dapat terlihat bahwa pada waktu 28 HST memiliki $F_{\text {hitung }}(5.841)>$ nilai $F_{\text {tabel }}$ (3.24), maka $\mathrm{H}_{0}$ ditolak dan dapat disimpulkan bahwa terdapat perbedaan pengaruh yang signifikan pada jumlah daun tanaman labu kuning pada cekaman salinitas.

Berdasarkan hasil penelitian pada 14 dan 21 HST tidak terdapat perbedaan pengaruh signifikan cekaman salinitas terhadap pertumbuhan jumlah daun tanaman labu kuning. Pada saat 28 dan 35 HST terdapat perbedaan pengaruh yang signifikan. Rata-rata jumlah daun terbanyak terdapat pada 
waktu pengamatan 35 HST yaitu pada perlakuan kontrol $\left(\mathrm{P}_{0}\right)$. Pada perlakuan konsentrasi $6000 \mathrm{ppm}$ $\left(\mathrm{P}_{3}\right)$ sangat berpengaruh terhadap pertumbuhan jumlah daun tanaman labu kuning, karena pada konsentrasi ini daun tanaman labu kuning mengalami pengurangan jumlahnya saat 28 hingga 35 HST.

Hasil penelitian dapat diketahui bahwa lamanya waktu tanam dapat mempengaruhi banyaknya jumlah daun tanaman labu kuning pada masingmasing perlakuan cekaman salinitas dengan pemberian larutan $\mathrm{NaCl}$ yang setiap konsentrasi kepekatannya berbeda. Selain itu, semakin tinggi kadar garam, maka jumlah daun yang dihasilkan akan semakin sedikit. Hal ini disebabkan karena perkembangan daun yang terhambat sehingga proses penuaan daun menjadi lebih cepat (Kurniasari $d k k .$, 2010).

Tabel 5. Pengaruh cekaman salinitas terhadap rerata jumlah daun tanaman labu kuning (Cucurbita moschata)

\begin{tabular}{ccccc}
\hline Perlakuan & $14 \mathrm{HST}$ & $21 \mathrm{HST}$ & $28 \mathrm{HST}$ & $35 \mathrm{HST}$ \\
\hline $\mathrm{P}_{0}$ & $2.8 \mathrm{a}$ & $3.8 \mathrm{a}$ & $5.2 \mathrm{c}$ & $5.8 \mathrm{~b}$ \\
$\mathrm{P}_{1}$ & $2.6 \mathrm{a}$ & $3.8 \mathrm{a}$ & $4.8 \mathrm{bc}$ & $5.2 \mathrm{~b}$ \\
$\mathrm{P}_{2}$ & $2.4 \mathrm{a}$ & $3.4 \mathrm{a}$ & $3.8 \mathrm{ab}$ & $4.8 \mathrm{~b}$ \\
$\mathrm{P}_{3}$ & $2.2 \mathrm{a}$ & $3.2 \mathrm{a}$ & $3.0 \mathrm{a}$ & $2.8 \mathrm{a}$ \\
\hline
\end{tabular}

Cekaman salinitas juga berpengaruh terhadap pertumbuhan tanaman yang menjadi tidak normal seperti daun mengering di bagian ujung dan gejala khlorosis (Jalil $d k k$., 2016). Beberapa peneliti mengungkapkan bahwa efek salinitas menyebabkan penutupan stomata dan penghambatan perkembangan daun serta selama periode yang lebih lama dan melibatkan penumpukan ion menyebabkan penuaan dini daun dan akhirnya mengurangi hasil (Dachlan $d k k$., 2013). Terlarutnya garam-garam akan menurunkan potensial air yang dapat mempercepat penuaan daun sehingga terjadinya pengurangan jumlah daun. Molekul $\mathrm{NaCl}$ yang mengalami ionisasi menjadi $\mathrm{Na}^{+}$dan $\mathrm{Cl}^{-}$sehingga terjadi peningkatan salinitas yang dapat menginduksi terjadinya stress ion, akibatnya pertumbuhan dan perkembangan sel-sel tanaman terhambat (Teare \& Peet, 1983 dalam Dachlan, 2013). Pengguguran daun adalah salah satu bentuk respon tanaman untuk mengurangi penguapan karena kekurangan air (Sobir $d k k ., 2018)$. Djukri (2009) menyebutkan salinitas dan luas daun biasanya memiliki hubungan yang terbalik yaitu peningkatan salinitas maka kehilangan air per tanaman melalui transpirasi berkurang. Selain itu salinitas tinggi menyebabjan fiksasi $\mathrm{CO}_{2}$ neto per unit luas daun juga dapat berkurang.

\section{Panjang Akar Tanaman Labu Kuning}

Pengukuran panjang akar tanaman labu kuning dilakukan saat umur 35 HST. Tanaman labu kuning memiliki jenis akar tunggang. Panjang akar tanaman labu kuning diukur mulai dari pangkal akar hingga ke ujung akar dengan menggunakan penggaris.

Pada uji hipotesis panjang akar tanaman labu kuning menggunakan uji ANOVA satu arah karena data berdistribusi normal serta didapatkan nilai $\mathrm{F}_{\text {tabel }}$ adalah $\alpha(5 \%)=0.05, \mathrm{dk}_{1}(\mathrm{k}-1)=4-1=$ 3 dan $\mathrm{dk}_{2}\left(\mathrm{n}_{\mathrm{T}}-\mathrm{k}\right)=20-4=16$. Jadi, nilai $\mathrm{F}_{\text {tabel }}$ yang didapat adalah 3.24. Nilai $F_{\text {hitung dari }}$ masing-masing perlakuan dapat dilihat pada Tabel 6.

Tabel 6. Uji ANOVA 1 Arah pada panjang akar tanaman labu kuning (Cucurbita moschata)

\begin{tabular}{cccc}
\hline $\begin{array}{c}\text { Waktu } \\
\text { (HST) }\end{array}$ & $\mathrm{F}_{\text {hitung }}$ & $\mathrm{F}_{\text {tabel }}$ & Keterangan \\
\hline 35 & 11.137 & 3.24 & $\begin{array}{l}\mathrm{H}_{0} \text { ditolak, } \\
\text { terima } \mathrm{H}_{1}\end{array}$ \\
\hline
\end{tabular}

Hasil uji hipotesis menggunakan ANOVA satu arah, dapat terlihat bahwa panjang akar tanaman labu kuning pada waktu hari penelitian terakhir yaitu 35 HST memiliki $F_{\text {hitung }}>$ nilai $F_{\text {tabel }}$, maka $\mathrm{H}_{0}$ ditolak dan dapat disimpulkan bahwa terdapat perbedaan pengaruh yang signifikan panjang akar tanaman labu kuning pada cekaman salinitas.

Panjang akar tanaman labu kuning mengalami pertumbuhan paling baik pada perlakuan kontrol atau $0 \mathrm{ppm}$. Sehingga dapat disimpulkan bahwa pertumbuhan panjang akar lebih baik apabila tidak adanya cekaman salinitas, sedangkan pada akar yang mengalami cekaman salinitas, semakin tinggi konsentrasi salinitasnya maka akar menjadi lebih pendek seperti halnya pada perlakuan $6000 \mathrm{ppm}$.

Pertumbuhan akar yang terhambat ini disebabkan oleh senyawa $\mathrm{Na}$ dari garam yang terserap pada akar sehingga mempengaruhi terhadap penyerapan unsur hara lain. Hal ini mengakibatkan terganggunya proses pertumbuhan akar (Junandi, 2019). Bahkan pada tanaman kedelai, gangguan pada akar juga tampak pada jumlah dan bobot bintil akar serta aktifitas nitrogenase yang diperankannya 
(Purwaningrahayu, 2016). Ditambahkannya bahwa peningkatan cekaman salinitas menyebabkan penurunan pertumbuhan yang tercermin dari penurunan bobot kering akar dan tajuk. Walaupun kondisi defisit air pada tanah salin, lebih cepat memperlihatkan pengaruh pada pertumbuhan pucuk dibandingkan panjang akar.

Tabel 7. Pengaruh cekaman salinitas terhadap panjang akar tanaman labu kuning (Cucurbita moschata)

\begin{tabular}{ccc}
\hline \multirow{2}{*}{ Perlakuan } & \multicolumn{2}{c}{$35 \mathrm{HST}$} \\
\cline { 2 - 3 } & Rata-rata $(\mathrm{cm})$ & Notasi \\
\hline $\mathrm{P}_{0}$ & 4.6 & $\mathrm{c}$ \\
$\mathrm{P}_{1}$ & 3.8 & $\mathrm{~b}$ \\
$\mathrm{P}_{2}$ & 3.5 & $\mathrm{ab}$ \\
$\mathrm{P}_{3}$ & 2.8 & $\mathrm{a}$ \\
\hline
\end{tabular}

Berdasarkan penelitian yang telah dilakukan pada parameter tinggi tanaman, jumlah daun, dan panjang akar yang diamati, pertumbuhan tanaman memerlukan kandungan unsur hara yang memenuhi. Adanya cekaman salinitas yang tinggi dapat mengganggu pertumbuhan tanaman, seperti tinggi tanaman yang terhambat, jumlah daun yang berkurang, dan pertumbuhan panjang akar lambat yang dapat mempengaruhi kemampuan akar dalam menyerap unsur hara yang dibutuhkan, sehingga pertumbuhan vegetatif tanaman dapat terganggu.

Lamanya waktu tanaman tercekam salinitas juga dapat berpengaruh terhadap respons tanaman labu kuning. Pada penelitian ini, hingga pada umur tanam 21 HST tidak terdapat pengaruh yang signifikan perlakuan cekaman salinitas terhadap pertumbuhan tanaman labu kuning. Hal ini karena tanaman labu kuning masih toleran terhadap konsentrasi tersebut. Keadaan tersebut diperkirakan terjadi karena konsentrasi tersebut belum direspon sebagai keadaan tercekam oleh tanaman. Sedangkan pada waktu tanam mulai dari 28 hingga 35 HST terdapat pengaruh cekaman salinitas yang signifikan terhadap tinggi tanaman, jumlah daun, dan panjang akar.

Walaupun tanaman dalam cekaman salinitas tidak menunjukkan kerusakan secara langsung, namun jika diamati dan diteliti, pertumbuhannya secara umum menjadi tidak normal (tertekan) dan berubah secara perlahan (Junandi, 2019). Walaupun pertumbuhan tanaman labu kuning tetap mengalami peningkatan, namun laju pertumbuhannya menjadi lambat. Jadi, tanaman labu kuning memiliki tingkat toleransi yang sedang terhadap cekaman salinitas. Tanaman peka atau toleran salinitas berbeda dalam kemampuan mentoleransi kadar garam hingga tingkat beracun di daun. Jangka waktu terjadinya respon juga berbeda bergantung pada spesies dan tingkat salinitasnya.

Djukri (2009) menjelaskan bahwa kondisi yang membahayakan dan bahkan pada tingkat tertentu bisa menimbulkan kematian, akan memacu tanaman untuk meningkatkan ketahanannya. Hal ini ditunjukkan dengan terbentuknya molekulmolekul tertentu di dalam sel, seperti prolin dan berbagai asam amino bebas lainnya, yang berperan dalam peningkatan ketahanan terhadap cekaman garam.

Agar tetap dapat menanam tanaman labu kuning di lahan salin, perlu memperhatikan ketersediaan air tanah yang cukup dan nutrisi bagi tanaman. Walaupun tingkat salinitas rendah, namun apabila tanah dalam keadaan kering dan kurangnya nutrisi, maka pertumbuhan tanaman labu kuning akan tetap tidak seperti normalnya. Oleh karena itu, tersedianya air yang cukup akan mengurangi pengaruh kekeringan akibat cekaman salinitas (Kurniasari $d k k ., 2010$ ) dan tercukupinya nutrisi akan membantu mendorong pertumbuhan tanaman labu kuning. Selain itu bisa dilakukan perlakuan pada tanah sehingga sesuai dengan kebutuhan tanaman, antara lain dengan penambahan bahan amelioran untuk meminimalkan pengaruh buruk unsur Natrium. Tindakan lain yang dapat dilakukan adalah melakukan pemulsaan untuk menurunkan evapotranspirasi dan akumulasi garam ke permukaan, menjaga kelembaban tanah di daerah perakaran, menurunkan suhu tanah, evaporasi, dan akumulasi garam (Purwaningrahayu \& Abdullah, 2018).

\section{KESIMPULAN}

Semakin tinggi kadar salinitas dan keberlangsungan tercekamnya semakin lama, maka pertumbuhan tanaman labu kuning (Cucurbita moschata) dapat terhambat dan menurun, meskipun laju pertumbuhan setiap minggunya tetap mengalami peningkatan. Hal ini diperkirakan terjadi karena konsentrasi garam tersebut belum direspon sebagai keadaan tercekam oleh tanaman labu kuning. Supaya tetap dapat menanam tanaman labu kuning di lahan salin, perlu memperhatikan ketersediaan air tanah yang cukup dan nutrisi bagi tanaman agar mampu mendorong pertumbuhannya.

\section{DAFTAR PUSTAKA}

Afifah, S. (2014). Respons Pucuk Kentang (Solanum tuberosum L.) In Vitro Terhadap 
Cekaman Salinitas. Skripsi. Universitas Pendidikan Indonesia.

Andriani, V. (2017). Pertumbuhan dan kadar klorofil tanaman pakcoy (Brassica rapa L.) terhadap cekaman NaCl. Stigma, 10(2), 5867.https://doi.org/10.36456/stigma.vol10.no2.a 1032.

Bastomi, M. Y. (2018). Efek Cekaman Salinitas $(\mathrm{NaCl})$ Terhadap Pertumbuhan Dua Varietas Cabai Rawit (Capsicum frustescens L.). Skripsi. Universitas Islam Negeri Maulana Malik Ibrahim.

Dachlan, A., Nurlina, K., \& A. K. S. (2013). Uji ketahanan salinitas beberapa varietas jagung (Zea mays L.) dengan menggunakan agen seleksi NaCl. Biogenesis, 1(1), 9-17. https://doi.org/10.24252/bio.v1i1.442.

Djukri. (2009). Cekaman Salinitas Terhadap Pertumbuhan Tanaman. In Seminar Nasional Penelitian, Pendidikan dan Penerapan MIPA, (hal 49-55). Yogyakarta. Fakultas MIPA, Universitas Negeri Yogyakarta.

Jalil, M., Halimatun, S., Eka, D., \& Ilham, A. (2016). Pertumbuhan dan produksi beberapa varietas padi (Oryza Sativa. L) pada berbagai tingkat salinitas. Jurnal Agrotek Lestari, 2(2), 63-74. https://doi.org/10.35308/jal.v2i2.597.

Junandi., Mukarlina., \& Linda, R. (2019). Pengaruh cekaman salinitas garam $\mathrm{NaCl}$ terhadap pertumbuhan kacang tunggak (Vigna unguiculata $\mathrm{L}$. Walp) pada tanah gambut. Protobiont, 8(3), 101-105. http://dx.doi.org/10.26418/protobiont.v8i3.368 69.

Kurniasari, A. M., Adiasyahputra., \& Rosihan, R. (2010). Pengaruh kekeringan pada tanah bergaram $\mathrm{NaCl}$ terhadap pertumbuhan tanaman nilam. Bul. Littro. 21(1), 18-27. http://dx.doi.org/10.21082/bullittro.v21n1.201 $0 . \% 25 p$.

Kusumiyati., Tino, M. O., \& Fajrianti, A. H. (2017). Pengaruh konsentrasi larutan garam $\mathrm{NaCl}$ terhadap pertumbuhan dan kualitas bibit lima kultivar asparagus. J. Hort, 27(1), 79-86. http://dx.doi.org/10.21082/jhort.v27n1.2017.p7 9-86

Novita, A., Julia, H., \& Rahmawati, N. (2019). Tanggap salinitas terhadap pertumbuhan bibit akar wangi (Vetiveria zizanioides L.). Agrica Ekstensia, 13(2), 55-58.
Prabowo, I., \& Rachmawati, D. (2020). Respon fisiologis dan anatomi akar tanaman bayam (Amaranthus tricolor L.) terhadap cekaman NaCl. Jurnal Penelitian Saintek, 25(1), 36-43. https://doi.org/10.21831/jps.v25i1.27357.

Purwaningrahayu, R. K. (2016). Karakter morfofisiologi dan agronomi kedelai toleran salinitas. Iptek Tanaman Pangan, 11(1), 35-48.

Purwaningrahayu, R. K., \& Abdullah T. (2018). Pemulsaan dan ameliorasi tanah salin untuk pertumbuhan dan hasil kedelai. Jurnal Agronomi Indonesia, 46(2), 182-188. https://dx.doi.org/10.24831/jai.v46i2.16517.

Sobir., Miftahudin., \& Susan, H. (2018). respon morfologi dan fisiologi genotipe terung (Solanum melongena L.) terhadap cekaman salinitas. J. Hort. Indonesia, 9(2), 131-138. http://dx.doi.org/10.29244/jhi.9.2.131-138.

Tavakkoli, E., Rengasamy, P., \& McDonald, G. K. (2010). High concentrations of $\mathrm{Na}+$ and $\mathrm{Cl}$ ions in soil solution have simultaneous detrimental effects on growth of faba bean under salinity stress. Journal of experimental botany, 61(15), 4449-4459. https://doi.org/10.1093/jxb/erq251.

Trustinah. (2020). Merakit Masa Depan Kacang Hijau di Tanah Bergaram. https://balitkabi.litbang.pertanian.go.id/infotek/ merakit-masa-depan-kacang-hijau-di-tanahbergaram. Diakses 10 Januari 2022.

Yamika. W. S. D., Nurul, A., \& Adi, S. (2016). Penentuan Batas Toleransi Salinitas Beberapa Tanaman (Tomat, Mentimun, Bawang Merah dan Cabai Besar) pada Cekaman Salinitas. In Seminar Nasional Pembangunan Pertanian, (hal 35-40). Malang. Fakultas Pertanian Universitas Brawijaya.

Yunita, R., Khumalda, N., Sopandle, D., \& Mariska, I. (2018). Analisis cekaman salinitas terhadap padi mutan pada kondisi in vitro. Penelitian Pertanian Tanaman Pangan, 2(1), 25-34.

http//dx.doi.org/10.21082/jpptp.v2n1.2018.p25 -34 .

Zufahmi., Suranto., \& Mahajoeno, E. (2015). Karakteristik Tanaman Labu Kuning (Cucurbita moschata) Berdasarkan Penanda Morfologi Dan Pola Pita Isozim Peroksidase. Seminar Nasional Biotik 2015 (pp. 266-273). Aceh, Indonesia: Program Studi Pendidikan Biologi, Universitas Islam Negeri Ar-Raniry. 


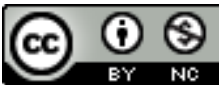

This work is licensed under a Creative Commons Attribution-NonCommercial 4.0 International License 